\title{
Potensi Ekstrak Daun Afrika (Vernonia amygdalina Delile) Sebagai Antibakterial Terhadap Bakteri Escherichia coli ATCC 25922
}

\author{
(THE POTENTIAL OF EXTRACT DAUN AFRIKA (Vernonia amygdalina Delile) FOR \\ ANTIBACTERIAL ACTIVITY TO BACTERIAL ISOLATES Escherichia coli ATCC
} 25922)

\author{
Fitriani Murjianingsih ${ }^{1 *}$, Suryanie Sarudji², Amung Logam Saputro ${ }^{3}$, Wiwiek \\ Tyasningsih $^{2}$, Iwan Sahrial Hamid ${ }^{4}$, Maya Nurwartanti Yunita ${ }^{5}$ \\ ${ }^{1}$ Bachelor of Veterinary Medicine, \\ ${ }^{2}$ Department of Veterinary Microbiology, \\ ${ }^{3}$ Department of Clinical Veterinary, \\ ${ }^{4}$ Department of Basic Veterinary Science, \\ ${ }^{5}$ Department of Veterinary Pathology, \\ Faculty of Veterinary Medicine, Universitas Airlangga, \\ UNAIR C-Campus Mulyorejo, Surabaya, Jawa Timur, Indonesia, 60115 \\ Telp. (031)5993016, Fax. (031)5993015 \\ *Corresponding author: fitriani.murjianings-2014@fkh.unair.ac.id
}

\begin{abstract}
Abstrak
Tujuan dari penelitian ini adalah untuk mengetahui potensi ekstrak metanol daun Afrika (Vernonia amygdalina Delile) sebagai antibakteri terhadap bakteri Escherichia coli ATCC 25922. Isolat E. coli dibiakan pada media Muller Hinton Agar (MHA). Uji antibakteri menggunakan metode difusi sumuran. Kontrol negatif (K-) pada lubang sumuran hanya diberikan pengencer ekstrak CMC Na 0,5\%. Kontrol positif (K+) pada lubang sumuran diberi dengan eugenol. Perlakuan (P1, P2, P3, P4) diberikan ekstrak metanol daun Afrika (Vernonia amygdalina Delile) dengan masing - masing konsentrasi 100\%, 75\%, 50\% dan $25 \%$. Rancangan penelitian menggunakan metode Rancangan Acak Lengkap (RAL), dengan enam perlakuan dan empat pengulangan. Data dianalisis dengan ANOVA, dilanjutkan dengan uji Duncan. Hasil analisis zona hambat menunjukkan, K+ memiliki perbedaan yang nyata dengan semua perlakuan K-, P1, P2, P3, dan P4. Serta K- ditemukan tidak berbeda nyata dengan perlakuan P1, P2, P3 dan P4. Hasil penelitian menunjukkan bahwa setiap perlakuan tidak menghasilkan zona hambat sehingga tidak berbeda nyata dengan kontrol negatif (CMC Na 0,5\%).
\end{abstract}

Kata kunci: aktivitas antibakteri, zona hambat, daun Afrika, Escherichia coli

\begin{abstract}
The aim of this study was to determine the potential of the methanol extract of daun Afrika (Vernonia amygdalina Delile) as an antibacterial against Escherichia coli ATCC 25922. Isolates E. coli was cultured on Muller Hinton Agar (MHA). The antibacterial test using a hole diffusion method. The negative control ( $K$-) was a hole with contain only the extract dilution CMC Na 0,5\%. Positive control $(K+)$ was a hole filled with eugenol. Treatment (P1, P2, P3, P4) were given the methanol extract of daun Afrika (Vernonia amygdalina Delile) with concentration of 100\%, 75\%, 50\% and 25\% respectively. Research design using Completely Randomized Design (RAL), with six treatments and four repetitions. The data was analyzed by ANOVA, followed by Duncan test. The results of the analysis of inhibition zone showed, $K+$ has clear difference with all treatments of $K$-, P1, P2, P3, and P4. As well $K$ - found not significant defferent with treatmets of P1, P2, P3 and $P 4$. The results showed that each treatment did not produce an inhibitory zone so it was not significantly different with the negative control ( $\mathrm{CMCNa} 0.5 \%)$.
\end{abstract}

Key words: antibacterial activity, inhibition zone, Vernonia amygdalina Delile, Escherichia coli 


\section{PENDAHULUAN}

World Health Organization (WHO) menyatakan tanaman obat dapat menjadi salah satu sumber terbaik untuk menghasilkan berbagai macam obat. Tanaman obat adalah tumbuhan yang salah satu atau lebih dari bagianbagiannya mengandung zat yang dapat digunakan untuk tujuan pengobatan. Pengobatan herbal di Indonesia semakin berkembang dikarenakan banyaknya temuan obat herbal terbaru yang dapat menyembuhkan penyakit. Obat herbal yang bersifat konstruktif dan memperbaiki jaringan serta mengembalikan fungsi sel menjadi salah satu kelebihan dibandingkan obat dari bahan kimia (Utami dan Puspaningtyas, 2013).

Meningkatnya penggunaan obat herbal dikarenakan penggunaan obat dari bahan kimia yang dapat menimbulkan efek samping, salah satunya resistensi bakteri yang diakibatkan penggunaan antibiotik yang tidak sesuai aturan (Yenny, 2007). Penelitian yang dilaporkan Krisnaningsih dkk. (2015), bakteri E. coli mengalami resistensi terhadap beberapa antibiotik. Escherichia coli adalah bakteri Gram negatif dari golongan enterobacteria, banyak ditemukan dalam pencernaan manusia, hewan, tanah, air, dan udara (Isholawati dkk., 2014; Fikri, dkk., 2017). Bakteri ini juga dapat menyebabkan diare enterotoksigenik pada hewan berdarah panas seperti sapi dan domba (McVey et al., 2013). Beberapa serotipe bakteri E.coli resisten terhadap satu atau beberapa antibiotik (Krisnaningsih, dkk., 2015; Fikri, dkk., 2018). Penelitian Oshim (2016) melaporkan ekstrak metanol daun Afrika dapat memberikan aktivitas antibakteri terhadap bakteri Escherchia coli.

Penelitian Oboh dan Masodjie (2009) menunjukkan ekstrak air daun Afrika (Vernonia amygdalina Delile) dapat menghambat pertumbuhan Staphylococcus aureus dan Escherichia coli dengan zona hambat $0,8 \mathrm{~cm}$. Daun afrika (Vernonia amygdalina Delile) mengandung beberapa senyawa bermanfaat untuk bahan baku obat seperti golongan saponin, flavonoid, tannin, alkaloid, niacin, anthraquinones, sesquiterpen lakton dan glikosida yang dapat berfungsi sebagai antibakterial (Ijeh and Ejike, 2010).

Daun Afrika (Vernonia amygdalina Delile) memiliki senyawa-senyawa yang dapat berfungsi sebagai antibakterial, sehingga untuk membuktikan bahwa daun Afrika memiliki potensi sebagai antibakterial terhadap bakteri $E$. coli yang sering ditemukan di lingkungan, serta untuk mengatasi permasalahan tentang resistensi antibiotik pada bakteri maka perlu dilakukan penelitian uji antibakterial ekstrak daun Afrika terhadap bakteri E. coli.

\section{METODE PENELITIAN}

Penelitian ini merupakan penelitian eksperimental laboratorium. Rancangan penelitian yang digunakan adalah Rancangan Acak Lengkap (RAL), dengan metode uji sensitivitas difusi sumuran. Isolat bakteri didapatkan dari Laboratorium Bakteriologi dan Mikologi Fakultas Kedokteran Hewan Universitas Airlangga Surabaya dan untuk uji sensitivitas dilakukan di Laboratorium Instumen 1 Program Studi Pendidikan Dokter Hewan PSDKU Universitas Airlangga di Banyuwangi.

Alat dan bahan yang digunakan dalam penelitian ini adalah ekstrak daun Afrika (Vernonia amygdalina Delile), bakteri Escherichia coli ATCC 25922, metanol, CMC $\mathrm{Na}$ 0,5\%, media Muller Hinton Agar, aquades steril, larutan standar Mc Farland 0,5, alkohol $70 \%, \mathrm{NaCl} 0,9 \%$, cawan petri, bunsen, pipet, vortex, rotary evaporator, inkubator, jarum ose, mikropipet, tabung reaksi, dan autoclav.

Prosedur penelitian yaitu pembuatan ekstrak metanol daun Afrika (Vernonia amygdalina Delile) dengan melarutkan 500 gram serbuk daun Afrika ke dalam metanol selama 2 hari, kemudian dilakukan penyaringan dan dievaporasi sehingga didapatkan ekstrak kental, ekstrak kental disimpan pada botol kaca steril (Oshim et al, 2016). Uji antibakteri dilakukan pada media MHA. Suspensi bakteri yang telah sesuai dengan standar Mc Farland 0,5 dimasukkan ke dalam media MHA dengan metode spread sebanyak $0,2 \mathrm{ml}$ menggunakan pipet, lalu diratakan menggunakan spatula, 
kemudian dibuat lubang sumuran dengan ukuran $6 \mathrm{~mm}$. Ekstrak dengan konsentrasi 100\%, 75\%, $50 \%$, dan $25 \%$ yang telah dilarutkan dengan CMC Na 0,5\% dimasukkan ke dalam lubang sumuran sebanyak $20 \mu \mathrm{l}$ menggunakan mikropipet. Eugenol sebagai kontrol positif dan CMC $\mathrm{Na}$ 0,5\% sebagai kontrol negatif juga dimasukkan kedalam lubang sumuran dengan ukuran yang sama. Media MHA kemudian di inkubasi dengan suhu $370 \mathrm{C}$ selama 24 jam (Oshim et al., 2016).

Pengukuran zona terang yang merupakan indikator terjadinya daya hambat antibakterial yang diujikan. Bontjura dkk (2015) menyatakan zona yang diamati yaitu zona bening dan kontras dengan biakan bakteri Escherichia coli yang berada di sekitar lubang sumuran. Diameter yang terlihat diukur dengan jangka sorong.

\section{HASIL DAN PEMBAHASAN}

Hasil uji antibakterial ekstrak daun Afrika (Vernonia amygdalina Delile) terhadap bakteri E. coli tidak menunjukkan hasil, dikarenakan tidak terbentuk zona hambat yang merupakan indikator terjadinya daya antibakterial.

Hasil analisis statistik pada tabel 1 dengan One Way Anova menunjukkan perbedaan yang nyata $(\mathrm{p}<0,05)$, kemudian dilanjutkan dengan uji Duncan Multiple Range Test dapat diketahui bahwa diameter daya hambat tertinggi diperoleh pada $\mathrm{K}(+)$ atau pada pemberian Eugenol 11,5 $\mathrm{mm}$ yang menunjukkan perbedaan nyata pada perlakuan P1, P2, P3, P4, dan $\mathrm{K}(-)$ sebagai kontrol negatif yaitu $0,00 \mathrm{~mm}$. Hasil menunjukkan bahwa setiap perlakuan tidak terdapat zona hambat sehingga tidak berbeda nyata dengan kontrol negatif (CMC Na 0,5\%).

Tabel 1. Rata-rata dan simpangan baku diameter zona hambat

\begin{tabular}{cc}
\hline $\mathbf{P}$ & Diameter zona hambat $(\mathbf{m m}) \dot{\mathbf{x}} \pm$ SD \\
\hline $\mathrm{K}-$ & $0,00^{\mathrm{a}} \pm 0,00$ \\
$\mathrm{~K}+$ & $1,15^{\mathrm{b}} \pm 0,21$ \\
$\mathrm{P} 1$ & $0,00^{\mathrm{a}} \pm 0,00$ \\
$\mathrm{P} 2$ & $0,00^{\mathrm{a}} \pm 0,00$ \\
$\mathrm{P} 3$ & $0,00^{\mathrm{a}} \pm 0,00$ \\
P4 & $0,00^{\mathrm{a}} \pm 0,00$ \\
\hline
\end{tabular}

Keterangan: Superskrip berbeda pada kolom yang sama menunjukkan perbedaan nyata $(p<0,05)$

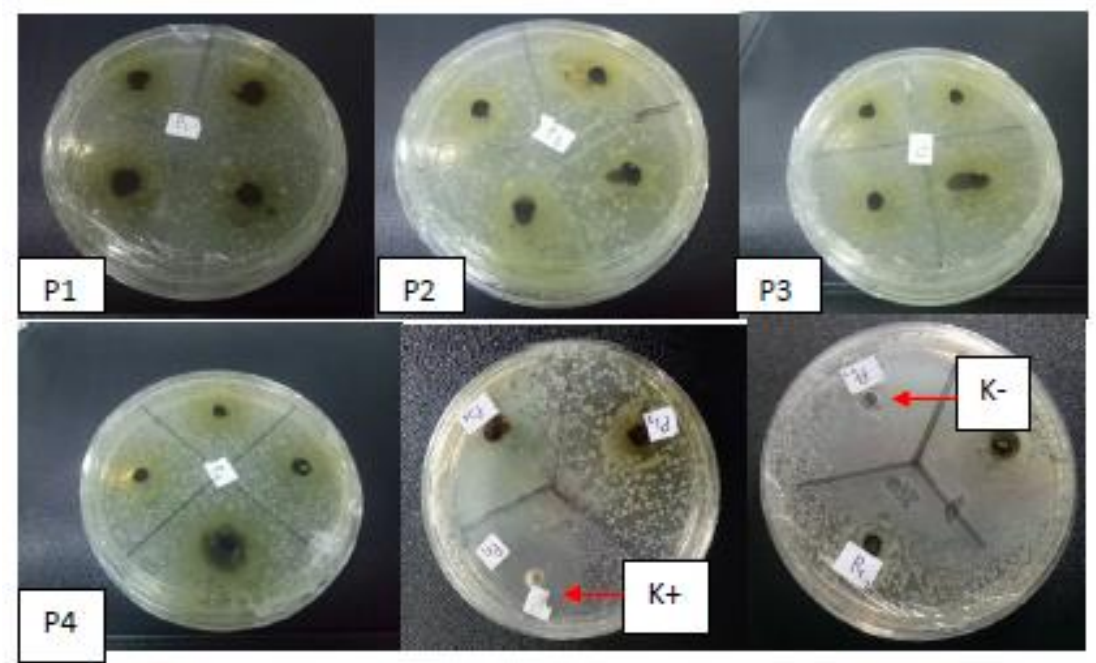

Gambar 1. (P1) ekstrak daun Afrika $100 \%$ tidak terbentuk zona hambat $(0,00 \mathrm{~mm})$; (P2) ekstrak daun Afrika $75 \%$ tidak terbentuk zona hambat $(0,00 \mathrm{~mm})$; (P3) ekstrak daun Afrika $50 \%$ tidak terbentuk zona hambat $(0,00 \mathrm{~mm})$; (P4) ekstrak daun Afrika (25\%) tidak terbentuk zona hambat $(0,00 \mathrm{~mm}) ;(\mathrm{K}-)$ pemberian $\mathrm{CMC} \mathrm{Na} 0,5 \%$ tidak terbentuk zona hambat $(0,00$ $\mathrm{mm}) ;(\mathrm{K}+)$ terbentuk zona hambat sebesar $11,5 \mathrm{~mm}$. 
Menurut Davis and Stout (1971), kriteria kekuatan daya antibakteri yaitu diameter zona hambat $5 \mathrm{~mm}$ atau kurang dikategorikan lemah, zona hambat 5-10 $\mathrm{mm}$ dikategorikan sedang, zona hambat 10-20 mm dikategorikan kuat dan zona hambat $20 \mathrm{~mm}$ atau lebih dikategorikan sangat kuat. Berdasarkan kriteria tersebut, maka daya antibakterial eugenol sebagai kontrol positif $(11,5 \mathrm{~mm})$ termasuk ke dalam kategori kuat, namun hasil pengamatan ekstrak daun afrika (Vernonia amygdalina Delile) terhadap bakteri E. coli ATCC 25922 pada perlakuan dengan konsentrasi 100\%, 75\%, 50\%, dan 25\% tidak dapat masuk ke dalam kategori manapun dikarenakan pada perlakuan menunjukkan tidak terjadinya respon antibakterial terhadap bakteri E. coli dengan dibuktikan tidak terbentuknya diameter zona hambat seperti pada gambar 1 .

Eugenol sebagai kontrol positif untuk dibandingkan efek antibakteri antara antiseptik dengan ekstrak daun Afrika. Pemilihan eugenol sebagai kontrol positif karena merupakan senyawa metabolit dalam tanaman cengkeh yang dapat berperan sebagai antibakterial (Towaha, 2012). Mekanisme antibakterial eugenol dengan menghancurkan dinding sel, merusak membran plasma, dan protein membran. Eugenol memiliki sifat hidrofobisitas yang dapat memisahkan lipid dari membran sel dan mitokondria bakteri (Reppi, 2016)

Diameter zona hambat yang tidak terbentuk pada perlakuan dapat disebabkan oleh beberapa faktor, diantaranya daya difusi ekstrak daun Afrika yang lemah, pelarut ekstraksi yang kurang tepat, serta konsentrasi bahan aktif yang rendah sehingga ekstrak daun Afrika tidak dapat menghambat pertumbuhan bakteri dengan baik. Faktor yang dapat mempengaruhi daya difusi agar, yaitu pradifusi mempengaruhi jarak difusi dari zat uji yaitu difusi antar lubang sumuran, ketebalan medium agar adalah penting untuk memperoleh sensitivitas yang optimal karena makin tebal media yang digunakan maka makin kecil diameter hambat yang terjadi, kerapatan inokulum yaitu jumlah inokulum yang lebih banyak menyebabkan daerah hambat yang kecil, komposisi media agar yang dapat mempengaruhi pertumbuhan bakteri serta kecepatan difusi zat, suhu inkubasi yang harus tepat yaitu 370C, waktu inkubasi disesuaikan dengan pertumbuhan bakteri karena luas daerah hambat ditentukan beberapa jam pertama, dan perbedaan $\mathrm{pH}$ media yang digunakan dapat menyebabkan perbedaan jumlah zat uji yang berdifusi (Rostinawati., 2009).

Jumlah konsentrasi ekstrak yang diberikan terlalu besar, sehingga dapat dimungkinkan difusi yang terjadi tidak maksimal menyebabkan senyawa metabolit yang masuk ke dalam agar rendah, sehingga tidak terbentuk diameter zona hambat sebagai indikator terjadinya proses antibakterial ekstrak daun Afrika terhadap bakteri E. coli.

Pelarut ekstraksi daun Afrika yang digunakan pada penelitian ini adalah metanol yang menunjukkan hasil kurang optimal, sesuai pada penelitian Oshim et al. (2016) yang menunjukkan bahwa ekstrak etanol daun Afrika lebih efektif dibandingkan dengan ekstrak metanol daun Afrika dengan menunjukkan daya hambat sebesar $24 \mathrm{~mm}$ pada bakteri Escherichia coli. Hal ini dikarenakan metanol tidak dapat menarik senyawa metabolit sekunder di dalam daun Afrika secara maksimal sehingga konsentrasi senyawa dalam ekstrak daun Afrika relatif kecil, dan tidak dapat memberikan efek antibakterial pada media uji sensitivitas.

\section{KESIMPULAN}

Ekstrak metanol daun Afrika (Vernonia amygdalina Delile) tidak memiliki pengaruh terhadap bakteri Escherichia coli yang dapat disebabkan oleh konsentrasi bahan aktif yang rendah.

\section{UCAPAN TERIMA KASIH}

Terimakasih kepada Laboratorium Program studi Pendidikan Dokter Hewan PSDKU Universitas Airlangga di Banyuwangi yang telah memfasilitasi pelaksanaan penelitian ini.

\section{DAFTAR PUSTAKA}


Bontjura, S., Waworuntu, O.A., Siagian, K.V. 2015. Uji Efek Antibakteri Ekstrak Daun Leilem (Clerodendrum minahassae L.) terhadap Bakteri Streptococcus mutans. Pharmacon Jurnal Ilmiah Farmasi UNSRAT, 4(4), 96-101.

Davis, W.W., Stout, T.R. 1971. Disc Plate Methods of Microbiological Antibiotic Assay. Microbiol., 22(4), 659-665.

Fikri, F., Hamid, I.S., Purnama, M.T.E. 2017. Uji organoleptis, $\mathrm{pH}$, uji eber dan cemaran bakteri pada karkas yang diisolasi dari kios di Banyuwangi. Jurnal Medik Veteriner, 1(1), 23-27.

Fikri, F., Purnama, M.T.E., Saputro, A.L., Hamid, I.S. 2018. Identifikasi Escherichia coli dan Salmonella spp pada Karkas Sapi di Rumah Potong Hewan di Banyuwangi dan Resistensi Terhadap Antibiotika. Jurnal Sain Veteriner, 36(1), 123-128.

Ijeh I.I., Igwe K.K., Ejike C.E.C.C. 2008. Effect of administration of aqueous extracts of Vernonia amygdalina .Del leaves to guinea pig dams on milk production and contraction of the mammary gland and uterus. African Journal of Traditional, Complementary and Alternative medicines, Abstracts of The World Congress on Medicinal and Aromatic Plants, Cape Town November. Abstract: $p$ 439-440.

Isholawati, D., Karamah, E.F., Zufri, Z.A., Hidayat, A.N. 2014. Disinfeksi Bakteri Escherichia Coli Menggunakan Proses Kavitasi Hidrodinamika Water-Jet Dengan Kombinasi Karbon Aktif Dan Zeolit. Prosiding SNST Fakultas Teknik, 1(1).

Krisnaningsih, M. F., Asmara, W., Wibowo, M.H. 2015. Uji Sensitivitas Isolat Escherichia coli Patogen pada Ayam terhadap Beberapa Jenis Antibiotik. Jurnal Sains Veteriner, 23(1).
McVey Neufeld, K.A., Mao, Y.K., Bienenstock, J., Foster, J.A., Kunze, W.A. 2013. The microbiome is essential for normal gut intrinsic primary afferent neuron excitability in the mouse. Neurogastroenterol. Motility, 25(2), 183-e88.

Oboh, F.O., Masodje, H.I. 2009. Nutritional and antimicrobial properties of Vernonia amygdalina leaves. Int. J. Biomed \& Hlth. Sci., 5(2).

Oshim, I.O., Desmond, C.O., Nwobu, R.A.U., Ezugwu, U.M., Urama, E.U. 2016. Kinetics of minimum inhibitory concentration, minimum bactericidal concentration and minimum fungicidal concentration of Vernonia amygdalina (Bitter leaf) on microorganisms isolated from wound infections. Int. J. Surg. Res., 5(1), 8-14.

Rostinawati, T. 2009. Aktivitas Antibakteri Ekstrak Etanol Bunga Rosella (Hibiscus Sabdariffa L.) Terhadap Escherichia Coli, Salmonella Typhi Dan Staphylococcus Aureus Dengan Metode Difusi Agar. Abstrak.

Reppi, N.B., Mambo, C., dan Wuisan, J. 2016. Uji Efek Antibakteri Ekstrak Kayu Manis (Cinnamomum burmanii) Terhadap Escherichia coli dan Streptococcus pyogenes. Jurnal e-Biomedik, 4(1).

Towaha, J. 2012. Manfaat eugenol cengkeh dalam berbagai industri di Indonesia. Perspektif, 11(2), 79-90.

Utami, P., Puspaningtyas, D.E. 2013. The Miracle of Herbs. PT AgroMedia Pustaka. Jakarta. p3-5.

Yenny, E.H. 2007. Resistensi dari Bakteri Enterik : Aspek Global terhadap Antimikroba. Universa Medicina, 26(1). 